\title{
Influence of Wastewater Type in the Effects Caused by Titanium Dioxide Nanoparticles in the Removal of Macronutrients by Activated Sludge
}

\section{Pabel Cervantes-Avilés ( $\sim$ pabel.cervantes@tec.mx )}

Tecnologico de Monterrey: Instituto Tecnologico y de Estudios Superiores de Monterrey https://orcid.org/0000-0001-9665-2959

Ayman N. Saber

Chinese Academy of Sciences

\section{Abrahan Mora Polanco}

Tecnologico de Monterrey: Instituto Tecnologico y de Estudios Superiores de Monterrey

\section{Jurgen Mahlknecht}

Tecnologico de Monterrey: Instituto Tecnologico y de Estudios Superiores de Monterrey

\section{Germán Cuevas-Rodríguez}

University of Guanajuato: Universidad de Guanajuato

\section{Research Article}

Keywords: TiO2, nanoparticles, elemental mapping, nanotoxicology, nitrification

Posted Date: April 23rd, 2021

DOI: https://doi.org/10.21203/rs.3.rs-380950/v1

License: (c) (i) This work is licensed under a Creative Commons Attribution 4.0 International License. Read Full License

Version of Record: A version of this preprint was published at Environmental Science and Pollution Research on September 7th, 2021. See the published version at https://doi.org/10.1007/s11356-021$16221-2$. 


\section{Abstract}

The imminent arrival of nanoparticles (NPs) to the wastewater treatment plants (WWTP) brings concern about their effects. In this work, the effects of titanium dioxide $\left(\mathrm{TiO}_{2}\right)$ NPs in the removal of carbon, nitrogen, and phosphorus by activated sludge bioreactors during the treatment of synthetic, raw and filtered wastewater were evaluated. The floc size, compaction of sludge, and morphological interactions between sludge and NPs were also evaluated. The main effect was observed in the ammoniacal nitrogen removal, which was inhibited up to $22 \%$ for all types of wastewater in the presence of $\mathrm{TiO}_{2} \mathrm{NPs}$. While nitrite production deficiencies were observed for real wastewaters experiments, nitrate formation was mainly affected for synthetic wastewater. The removal of organic matter was affected by $\mathrm{TiO}_{2} \mathrm{NPs}$ in lower level (up to $6 \%$ ) than nitrogen removal, especially during treatment of raw wastewater. The removal of orthophosphate was improved in presence of NPs $34 \%, 16 \%$ and $55 \%$ for synthetic, raw, and filtered wastewater, respectively. The compaction of the sludge was also a positive effect, which enhanced as the concentration of NPs increased without alterations in the floc size for all types of wastewater. Based on TEM and STEM imaging, the main interaction of $\mathrm{TiO}_{2} \mathrm{NPs}$ with activated sludge flocs was mainly the adsorption of NPs on the cell membrane. This means that NPs can disrupt the cell membrane during aerobic wastewater treatment. The effects of NPs on macronutrient removal depended on wastewater characteristics. The use of realistic matrices is highly encouraged for ecotoxicological experiments.

\section{Introduction}

$\mathrm{TiO}_{2}$ nanoparticles $\left(\mathrm{TiO}_{2} \mathrm{NPs}\right)$ are present in multiple everyday products such as food, toothpaste, sunscreens, among others (Weir et al. 2012). According to life cycle assessment studies (Keller and Lazareva, 2013; Adam et al., 2018;), the unintentional release of $\mathrm{TiO}_{2}$ NPs to the environment during or after the use of such products is expected. The potential arrival of $\mathrm{TiO}_{2} \mathrm{NPs}$ to environmental matrices, such as air, soil, or water, has raised concerns about their impacts. Water streams have been identified as the main transport media of $\mathrm{NP}_{\mathrm{S}}$ in the environment due to the connection between treated effluents and water bodies (Brar et al. 2010; Kunhikrishnan et al. 2015). Some studies have reported the presence of $\mathrm{TiO}_{2}$ NPs in wastewater streams (Kiser et al. 2009; Tuoriniemi et al. 2012), even in the sludge of the bioreactors applied for wastewater treatment (Polesel et al. 2018; Huang et al. 2020; Cervantes-Avilés and Keller 2021). Hence, the interaction between these NPs and microorganisms may damage the performance of the wastewater treatment process.

Several effects of $\mathrm{TiO}_{2}$ NPs during aerobic wastewater treatment have already been reported, including toxicity to some microorganisms of the aerobic processes (Li et al. 2017) and inhibition of oxygen consumption (Supha et al. 2015; Zhou et al. 2015). Deficiency in oxygen consumption could negatively affect the removal of carbon, nitrogen, and phosphorus in the aerobic bioreactors. Gartiser et al. (Gartiser et al. 2014) exposed an activated sludge system to $\mathrm{TiO}_{2}$ NPs during a period of 32 days and found that the cumulative effect of up to $840 \mathrm{mg} / \mathrm{L}$ of $\mathrm{TiO}_{2} \mathrm{NPs}$ negatively affected the removal of organic matter. 
These adverse effects were mainly related to the stability of the NPs (Zhou et al. 2015), which can change according to wastewater characteristics (Gartiser et al. 2014; Cervantes-Avilés et al. 2017).

Studies about the effects of $\mathrm{TiO}_{2} \mathrm{NPs}$ on the removal of ammoniacal nitrogen and phosphorus in activated sludge systems are limited. In the few studies, no impact of $\mathrm{TiO}_{2} \mathrm{NPs}$ on nitrogen and phosphorus removal was reported in activated sludge process exposed to 1, 10, and $50 \mathrm{mg} / \mathrm{L}$ during 24 days (Supha et al. 2015). In contrast, for higher concentrations of $\mathrm{TiO}_{2} \mathrm{NPs}$, an inhibitory effect on nitrogen removal has been observed, which has been attributed to the inhibition of microorganims related to nitrification-denitrification processes (Li et al. 2020). In the experiment of Garcia et al. (García et al. 2012), the nitrification rate was inhibited $5 \%$ in a treatment with suspended biomass system of 4 hour. Inhibition of the nitrification process was also observed in long-term experiments performed by Zheng et al. (Zheng et al. 2011). In these experiments, $50 \mathrm{mg} / \mathrm{L}$ of $\mathrm{TiO}_{2} \mathrm{NPs}$ were spiked in an activated sludge bioreactor, decreasing the ammoniacal nitrogen removal from 80.3 to $24.4 \%$ after 70 days.

The previous findings suggest that the effect of $\mathrm{TiO}_{2} \mathrm{NPs}$ on macronutrient removal depends on several factors, such as the accumulated concentration of $\mathrm{TiO}_{2} \mathrm{NPs}$ in bioreactors, the exposure time, and type of wastewater (Zheng et al. 2011; García et al. 2012; Li et al. 2020). Although there are not studies that demonstrate the relationship of these factors, research is needed to consider the impact of $\mathrm{TiO}_{2} \mathrm{NPs}$ on the simultaneous removal of macronutrients in aerobic bioreactors This work aimed to evaluate the effect of $\mathrm{TiO}_{2}$ NPs on macronutrient removal during the activated sludge process treating three types of domestic wastewaters: synthetic, raw, and filtered. The floc size, the compaction of the activated sludge and the morphological interaction between $\mathrm{TiO}_{2} \mathrm{NPs}$ and microorganisms were also evaluated for all types of wastewater.

\section{Materials And Methods \\ 2.1 Materials}

Milli-Q water with a resistivity of $18.2 \mathrm{M} \Omega \mathrm{cm}$ (Merck Millipore) was used in all suspensions of NPs and solutions. $\mathrm{TiO}_{2} \mathrm{NPs}$ were obtained as powder from ID-Nano (Mexico). Characterization results of $\mathrm{TiO}_{2}$ NPs are reported in Sect. 2.3. Synthetic wastewater (SWW) was prepared according to previous study (Cervantes-Avilés et al. 2017). Briefly, two main solutions, macronutrient and micronutrient solutions were mixed. Macronutrient solution contained: $1902.20 \mathrm{mg} / \mathrm{L} \mathrm{C}_{6} \mathrm{H}_{12} \mathrm{O}_{6}$ (Sigma-Aldrich), $344.25 \mathrm{mg} / \mathrm{L} \mathrm{NH}_{4} \mathrm{Cl}$ (Fisher Scientific), $72.42 \mathrm{mg} / \mathrm{L} \mathrm{K}_{2} \mathrm{HPO}_{4}$ (Fisher Scientific), $44.21 \mathrm{mg} / \mathrm{L} \mathrm{MgSO}_{4} \cdot 7 \mathrm{H}_{2} \mathrm{O}$ (Fisher Scientific), $18.56 \mathrm{mg} / \mathrm{L} \mathrm{CaCl} 2 \cdot 2 \mathrm{H}_{2} \mathrm{O}$ (Fisher Scientific) and $71.40 \mathrm{mg} / \mathrm{L} \mathrm{NaCl}$ (Sigma-Aldrich). An aliquot of $50 \mathrm{~mL}$ of the micronutrient solution was diluted in the macronutrient solution to reach the following concentrations in the SWW: $0.18 \mathrm{mg} / \mathrm{L} \mathrm{MgCl} \cdot 4 \mathrm{H}_{2} \mathrm{O}$ (Fisher Scientific), $0.29 \mathrm{mg} / \mathrm{L} \mathrm{H}_{3} \mathrm{BO}_{3}$ (Fisher Scientific), $0.10 \mathrm{mg} / \mathrm{L}$ $\mathrm{ZnCl}_{2}$ (Fisher Scientific), $0.27 \mathrm{mg} / \mathrm{L} \mathrm{FeCl}_{3}$ (Fisher Scientific) and $0.28 \mathrm{mg} / \mathrm{L} \mathrm{C}_{10} \mathrm{H}_{16} \mathrm{~N}_{2} \mathrm{O}_{8}$ (Sigma-Aldrich). $\mathrm{NaOH} 1 \mathrm{M}$ (Sigma-Aldrich) and $\mathrm{HNO}_{3} 1 \mathrm{M}$ (Fisher Scientific) were used to adjust to $\mathrm{pH} 7$ in SWW. 
Evaluation of macronutrients removal was performed in glass reactors of $2 \mathrm{~L}$, which were covered from light to avoid photolysis induced by $\mathrm{TiO}_{2} \mathrm{NPs}$. Each reactor was equipped with air diffusers and an air pump that provided air flux at $4 \mathrm{~m}^{3}{ }_{\text {air }} / \mathrm{h} \cdot \mathrm{m}^{3}$ reactor. Commercial tests were used to measure the concentration of chemical oxygen demand (COD), soluble COD (SCOD), ammoniacal nitrogen $\left(\mathrm{NH}_{3}-\mathrm{N}\right)$, nitrate-nitrogen $\left(\mathrm{NO}_{3}-\mathrm{N}\right)$, nitrite-nitrogen $\left(\mathrm{NO}_{2}-\mathrm{N}\right)$, and orthophosphate $\left(\mathrm{PO}_{4}{ }^{-3}\right)$ (Hach-Lange). The dissolved total organic carbon (dTOC) was measured in a TOC-L (Shimadzu). Nylon filters (Whatman) with a pore size of $0.45 \mu \mathrm{m}$ were used to remove the suspended solids before analysis. Glass fiber filters (Whatman) with a pore size of $0.7 \mu \mathrm{m}$ were used to determine the concentration of total suspended solids (TSS) and volatile suspended solids (VSS) according to the standard methods (APHA 2005).

The sludge samples were prepared for transmission electron microscopy (TEM) imaging by using ethanol absolute (Sigma-Aldrich), glutaraldehyde 10\% (Electron Microscopy Sciences, EMS), sodium cacodylate at pH of 7.4 (EMS), osmium tetroxide 10\% (EMS), propylene oxide (EMS), and epoxy embedding medium kit EPON812. Copper grids of 200 mesh (EMS) were used for TEM observation.

\subsection{Wastewater characterization}

Three types of wastewater, SWW, raw wastewater (RWW), and filtered wastewater (FWW), were tested separately in the reactors. SWW was prepared based on the constituents and procedure reported in materials section. Raw wastewater was collected in the septic tank of a house without access to sanitation services in Guanajuato, Mexico. FWW consisted of RWW without TSS, hence the collected RWW was passed through $0.45 \mu \mathrm{m}$ filters. The three types of wastewater were characterized to determine COD, sCOD, BOD, $\mathrm{NH}_{3}-\mathrm{N}, \mathrm{NO}_{3}-\mathrm{N}, \mathrm{NO}_{2}-\mathrm{N}, \mathrm{PO}_{4}{ }^{-3}$, TSS and VSS (Table 1). 
Table 1

Physicochemical characteristics of the three types of wastewater: Synthetic wastewater (SWW), raw wastewater (RWW) and filtered wastewater (FWW). SD stands for standard deviation, Min means minimum, and Max is short for maximum. $\mathrm{BOD}_{5}$ : biological oxygen demand at 5 days.

\begin{tabular}{|c|c|c|c|c|c|c|c|}
\hline \multirow[t]{2}{*}{ Parameter } & \multirow[t]{2}{*}{ Units } & \multicolumn{2}{|l|}{ swW } & \multicolumn{2}{|l|}{ RWW } & \multicolumn{2}{|l|}{ FWW } \\
\hline & & Min - Max & $\begin{array}{l}\text { Mean } \pm \\
\text { SD }\end{array}$ & $\begin{array}{l}\text { Min - } \\
\text { Max }\end{array}$ & $\begin{array}{l}\text { Mean } \pm \\
\text { SD }\end{array}$ & $\begin{array}{l}\text { Min - } \\
\text { Max }\end{array}$ & $\begin{array}{l}\text { Mean } \pm \\
\text { SD }\end{array}$ \\
\hline Temp. & ${ }^{\circ} \mathrm{C}$ & - & 20.7 & - & 23.7 & - & 23.1 \\
\hline $\mathrm{pH}$ & & - & $7 \pm 0.1$ & - & 8.18 & - & 8.20 \\
\hline Conductivity & $\mu \mathrm{S} / \mathrm{cm}$ & - & 889 & - & 1987 & - & 1934 \\
\hline TSS & $\mathrm{mg} / \mathrm{L}$ & - & - & $86-104$ & $95 \pm 9$ & - & - \\
\hline VSS & $\mathrm{mg} / \mathrm{L}$ & - & - & $74-82$ & $78 \pm 3$ & - & - \\
\hline COD & $\mathrm{mg} / \mathrm{L}$ & - & - & $495-522$ & $508 \pm 13$ & - & - \\
\hline sCOD & $\mathrm{mg} / \mathrm{L}$ & $\begin{array}{l}1909- \\
1931\end{array}$ & $1920 \pm 11$ & $455-473$ & $464 \pm 9$ & $\begin{array}{l}445- \\
466\end{array}$ & $455 \pm 11$ \\
\hline $\mathrm{BOD}_{5}$ & $\mathrm{mg} / \mathrm{L}$ & $\begin{array}{l}1550- \\
1570\end{array}$ & $1560 \pm 10$ & $345-375$ & $360 \pm 15$ & $\begin{array}{l}320- \\
335\end{array}$ & $328 \pm 8$ \\
\hline $\mathrm{NH}_{3}-\mathrm{N}$ & $\mathrm{mg} / \mathrm{L}$ & $81-89$ & $85 \pm 3$ & $128-138$ & $133 \pm 7$ & $\begin{array}{l}123- \\
128\end{array}$ & $125 \pm 3$ \\
\hline $\mathrm{NO}_{3}-\mathrm{N}$ & $\mathrm{mg} / \mathrm{L}$ & $<0.3$ & $<0.3$ & $3.8-5.0$ & $4.4 \pm 0.5$ & $3.9-5.2$ & $4.5 \pm 0.6$ \\
\hline $\mathrm{NO}_{2}-\mathrm{N}$ & $\mathrm{mg} / \mathrm{L}$ & $<0.01$ & $<0.01$ & $\begin{array}{l}0.08- \\
0.12\end{array}$ & $0.1 \pm 0.03$ & $\begin{array}{l}0.08- \\
0.1\end{array}$ & $\begin{array}{l}0.09 \pm \\
0.01\end{array}$ \\
\hline $\mathrm{PO}_{4}{ }^{3-}$ & $\mathrm{mg} / \mathrm{L}$ & $39-44$ & $42 \pm 2$ & $73-83$ & $77 \pm 5$ & $68-77$ & $73 \pm 5$ \\
\hline
\end{tabular}

\subsection{Characterization of the $\mathrm{TiO}_{2} \mathrm{NPs}$}

Stock suspension of $\mathrm{TiO}_{2} \mathrm{NPs}(2 \mathrm{~g} / \mathrm{L})$ was prepared in Milli-Q water and it was ultrasonicated during $1 \mathrm{~h}$ at $40 \mathrm{kHz}$ and $200 \mathrm{~W}$, as recommended to promote dispersibility for ecotoxicological assessment (Taurozzi et al. 2012). The primary size, shape, purity, phase and UV spectrum were determined in a previous study (Cervantes-Avilés et al. 2018). Briefly, $\mathrm{TiO}_{2}$ NPs were spherical with mean diameter ranging from 3 to $10 \mathrm{~nm}$ and were found in the anatase phase. Energy-dispersive X-ray spectroscopy (EDS) confirmed the purity, detecting $\mathrm{Ti}$ and $\mathrm{O}$ in the NPs. Finally, the localized surface plasmon resonance was detected at $295 \mathrm{~nm}$. Before spiking the experiments, $\mathrm{TiO}_{2}$ NPs stock suspension was ultrasonicated again during $1 \mathrm{~h}$ at same frequency and intensity.

\subsection{Macronutrient removal tests in activated sludge}


The reactors contained three main components, $0.842 \mathrm{~L}$ of inoculum of activated sludge, $0.842 \mathrm{~L}$ of wastewater and $0.316 \mathrm{~L}$ of $\mathrm{TiO}_{2} \mathrm{NPs}$ suspension or Milli-Q water for controls. Inoculum of activated sludge had a concentration of $3120 \pm 210 \mathrm{mg} / \mathrm{L}$ of SSV and was collected from a pilot plant operated in the laboratory during 60 days before the experiment. During that time, pilot plant was fed with SWW. The inoculum fed to the reactors was exposed to final concentrations of $500,1000,1500$, and $2000 \mathrm{mg} / \mathrm{L}$ of $\mathrm{TiO}_{2} \mathrm{NPs}$. All concentrations of $\mathrm{TiO}_{2} \mathrm{NPs}$ and controls were performed the same time with three replicates for each type of wastewater. The physicochemical parameters such as SCOD, dTOC, N-NH ${ }_{3}, \mathrm{~N}-$ $\mathrm{NO}_{3}, \mathrm{~N}-\mathrm{NO}_{2}, \mathrm{P}_{-} \mathrm{PO}_{4}$, and the sludge volumetric index (SVI) were determined per triplicate in all systems at the end of the tests. The time of exposure of activated sludge to NPs was 8 hours, which is the typical hydraulic retention time of the conventional WWTPs. The results of the physicochemical parameters were processed by ANOVA one factor. Dunnett's test was applied to determine the significant difference between groups. Moreover, statistical analysis was performed for each type of wastewater. Results with p-value $<0.05$ were considered statistically significant.

\subsection{Interactions between $\mathrm{TiO}_{2} \mathrm{NPs}$ and activated sludge}

Morphological interactions between flocs of activated sludge and NPs were studied at the end of the macronutrient removal tests by measuring the size of the flocs and observing flocs exposed to $\mathrm{TiO}_{2} \mathrm{NPs}$ through TEM and High angle annular dark field scanning-transmission electron microscopy (HAADFSTEM) imaging. The size of the flocs was determined by static light scattering (SLS, Microtrac S3500); 1.81 was applied as the refractive index of the floc. For TEM imaging, samples of activated sludge ( 1.5 $\mathrm{mL}$ ) were collected immediately after macronutrient removal tests and centrifuged at $9000 \mathrm{~g}$. The supernatant was replaced by $2.5 \%$ glutaraldehyde and pellets were resuspended and kept at room temperature for $2 \mathrm{~h}$. Then, samples were centrifuged to replace the glutaraldehyde with $1 \%$ osmium in sodium cacodylate $0.1 \mathrm{M}$, keeping the samples at room temperature for $1 \mathrm{~h}$. After this period, samples were dehydrated gradually with ethanol absolute, starting at $10 \%(\mathrm{v} / \mathrm{v})$ up to ethanol $100 \%$. Finally, samples were embedded in an epoxy resin (EPON812). The resin blocks were cut in thin sections, between $60-90 \mathrm{~nm}$, with an ultramicrotome (MTX-RMC). TEM imaging was conducted at $80 \mathrm{kV}$ in a JEOL-1010; HAADF-STEM was performed at $300 \mathrm{kV}$ in a microscope FEl-Titan 80-300.

\section{Results And Discussion}

\subsection{Removal of organic matter in presence of $\mathrm{TiO}_{2} \mathrm{NPs}$}

The removal of organic matter in the three types of wastewater was evaluated by relating the initial and final concentration ( $\left.\mathrm{C} / \mathrm{C}_{0}\right)$ of SCOD and dTOC (Fig. 1 ), which serves as indicative such removal in presence of $\mathrm{TiO}_{2} \mathrm{NPs}$. According to these results, the control groups presented removal of SCOD higher than $70 \%$ for the three types of wastewater (Fig. 1A), which corresponds to the typical removal for activated sludge systems (van Loosdrecht et al. 2016). However, the impact of $\mathrm{TiO}_{2} \mathrm{NPs}$ on SCOD removal was different for all types of wastewater. Activated sludge treating SWW was not affected in the 
presence of all $\mathrm{TiO}_{2}$ NPs concentrations, in terms of SCOD removal, which were statistically similar to its control group. Conversely, in the case of RWW and FWW, the removal of SCOD decreased linearly as the concentration of $\mathrm{TiO}_{2}$ NPs increased, reaching up to $10 \%$ and $14 \%$ lower removal for RWW and FWW, respectively. Since experimental conditions were similar for all three wastewaters, the negative effect of $\mathrm{TiO}_{2}$ NPs over SCOD removal can be attributed to the type of wastewater and concentration of NPs. Although the lowest SCOD removal was observed for real wastewater without suspended solids (FWW), there was no effect for assays with SWW at the experimental concentration of NPs. The non-influence of the $\mathrm{TiO}_{2}$ NPs suspended in synthetic substrates on the removal of organic matter during activated sludge experiments has been already reported (García et al. 2012; Qiu et al. 2016). In contrast, $\mathrm{TiO}_{2} \mathrm{NPs}$ in real wastewater have decreased the oxygen uptake during aerobic experiments (Zhou et al. 2015), limiting the oxidation of organic matter and leading to a decrease in the removal of SCOD. Although the removal of SCOD from RWW, which is more realistic matrix, was affected only $10 \%$ in presence of high load of $\mathrm{TiO}_{2}$ NPs, this removal is sensible to the wastewater characteristics, including the suspended solids content.

The removal of dTOC in the control reactors was at least 70\% for the three types of wastewater (Fig. 1B). However, the organic carbon removal was most affected for RWW containing concentrations higher than $1000 \mathrm{mg} / \mathrm{L}$ of $\mathrm{TiO}_{2}$ NPs, which affected the removal of dTOC up to $6 \%$. In contrast, the removal of organic carbon in experiments using SWW and FWW was not affected at all. This means that the presence of high concentrations of $\mathrm{TiO}_{2} \mathrm{NPs}$ in activated sludge process can have a slight effect on the removal of organic matter. A minimum adverse effect on organic matter removal was also found by a similar study performed by Gartiser et al. (2014), who fed synthetic wastewater based on peptone and meat extract and exposed an activated sludge reactor to $840 \mathrm{mg} / \mathrm{L}$ of $\mathrm{TiO}_{2} \mathrm{NPs}$ and induced a deficiency of $7 \%$ in the organic matter removal.

The removal of SCOD was more affected than the dTOC removal by the presence of $\mathrm{TiO}_{2} \mathrm{NPs}$. In the experiments with real wastewaters (RWW and FWW), the most adverse effects were observed on SCOD removal. This means that the oxidizable (bio or chemically) inorganic compounds were not removed by the aerobic microorganisms present in the activated sludge due to the occurrence of $\mathrm{TiO}_{2} \mathrm{NPs}$. The poor performance of aerobic microorganisms can be confirmed by previous experiments treating real wastewater in presence of $\mathrm{TiO}_{2} \mathrm{NPs}$, which inhibited the oxygen consumption by activated sludge in higher levels than SWW (Cervantes-Avilés et al. 2017). Therefore, since dTOC was not affected considerably in this experiment, the $\mathrm{TiO}_{2} \mathrm{NPs}$ in the RWW or FWW could affect the microorganisms responsible for the oxidation of the inorganic compounds measured as SCOD in wastewater. This is in line with previous reports which has found a decrease of the viable bacteria of the genera related to the aerobic activity in activated sludge due to the presence of $\mathrm{TiO}_{2} \mathrm{NPs}$ (Ma et al. 2015). Another study reported changes in bacterial diversity of activated sludge exposed to $1 \mathrm{mg} / \mathrm{L}$ of $\mathrm{TiO}_{2} \mathrm{NPs}$ for 40 days, which decreased from the second day of exposure to NPs (Qiu et al. 2016). The effect of $\mathrm{TiO}_{2}$ NPs in the activated sludge is a decrease in the SCOD removal when real wastewater is used, which could be attributed to the damage of aerobic microorganisms. 
Besides the type of wastewater, the SCOD removal alterations also depended on the concentration of NPS in the performed experiments. The wastewater characteristics and the concentration of NPs are related to the particle stability in aqueous media (Keller et al. 2010; Zhou et al. 2015). This may result in stable dispersion or formation of aggregates. Some studies have reported that $\mathrm{TiO}_{2} \mathrm{NPs}$ may form heteroaggregates (e.g. suspended solids of the wastewater and organic colloids linked to NPs) (Gartiser et al. 2014), which could be deposited in activated sludge flocs and induce a toxic effect on bacteria, such as physical or chemical damage in the cell membrane. The formation of heteroaggregates containing $\mathrm{TiO}_{2} \mathrm{NPs}$, organic colloids, and suspended solids has been related to the carbon/nitrogen $(\mathrm{C} / \mathrm{N})$ ratio in wastewater. The most stable and small heteroaggregates have been found at low $\mathrm{C} / \mathrm{N}$ ratio is close to 1 (Hotze et al. 2010; Keller et al. 2010). In this work, the C/N ratio for RWW and FWW was 1.27 and 1.22 , respectively, while the $\mathrm{C} / \mathrm{N}$ ratio for the SWW was 8.18 . Thus, the formation of small and stable heteroaggregates in real wastewaters may explain a potential damage in aerobic microorganisms. Besides, the presence of TSS may alter the effects of NPS on SCOD and dTOC removal. This means that the type of organic substrate and suspended solids content in wastewater plays an important role when evaluating toxicity by NPs.

\subsection{Ammoniacal nitrogen removal in presence of $\mathrm{TiO}_{2} \mathrm{NPs}$}

The ammoniacal nitrogen removal in activated sludge is mainly via nitrification-denitrification. In the control experiments using the three types of wastewater, the ammoniacal nitrogen removals were $64 \%$ for RWW and FWW, and 76\% for SWW (Fig. 2). These removal percentages are commonly observed in activated sludge reactors treating domestic wastewater. However, when the activated sludge was exposed to $\mathrm{TiO}_{2} \mathrm{NPs}$, the ammoniacal nitrogen removal was negatively affected for the three types of wastewater, with the only exception of FWW containing $500 \mathrm{mg} / \mathrm{L}$ that presented similar removal than control group (Fig. 2).

The removal of ammoniacal nitrogen in SWW containing $\mathrm{TiO}_{2} \mathrm{NPs}$ was less affected than for the other types of wastewater, decreasing the removal between $5 \%$ and $10 \%$ for all $\mathrm{TiO}_{2} \mathrm{NPs}$ concentrations (Fig. 2). Interestingly, the highest inhibition (10\%) of ammoniacal nitrogen removal was observed in the presence of $500 \mathrm{mg} / \mathrm{L}$ of $\mathrm{TiO}_{2} \mathrm{NPs}$ and decreased as the $\mathrm{TiO}_{2} \mathrm{NPs}$ content increased. Conversely, experiments with RWW and FWW indicated that inhibition of ammoniacal nitrogen removal increased as the concentration of $\mathrm{TiO}_{2} \mathrm{NPs}$ in activated sludge increased. In experiments with RWW, ammoniacal nitrogen removal decreased $22 \%$ in the presence of $2000 \mathrm{mg} / \mathrm{L}$ of $\mathrm{TiO}_{2} \mathrm{NPs}$, while for $\mathrm{FWW}$, the removal decreased $12 \%$ for the same concentrations of NPs. These results clearly indicate that the effect of $\mathrm{TiO}_{2}$ NPs on ammoniacal nitrogen removal was more severe when real wastewater with suspended solids is used.

In order to assess the ammoniacal nitrogen oxidation process, $\mathrm{NO}_{2}-\mathrm{N}$ and $\mathrm{NO}_{3}-\mathrm{N}$ concentrations were determined at the end of the macronutrient removal tests (Figs. 3A and 3B, respectively). In the case of SWW trials, the $\mathrm{NO}_{2}-\mathrm{N}$ formation in presence of $\mathrm{TiO}_{2} \mathrm{NPs}$ were similar to the control. However, the $\mathrm{NO}_{3}-\mathrm{N}$ 
formation decreased as the concentration of $\mathrm{TiO}_{2} \mathrm{NPs}$ increased. Hence, for SWW containing $\mathrm{TiO}_{2} \mathrm{NPs}_{\text {, }}$ the main effect occurred in the second step of the nitrification process.

Formation of $\mathrm{NO}_{2}-\mathrm{N}$ and $\mathrm{NO}_{3}-\mathrm{N}$ from RWW containing $\mathrm{TiO}_{2} \mathrm{NPs}$ was higher or similar to the control group, e.g., $\mathrm{NO}_{3}-\mathrm{N}$ production increased $7 \%$ in presence of $2000 \mathrm{mg} / \mathrm{L}$ of $\mathrm{TiO}_{2} \mathrm{NPs}$ compared to control group. Conversely, in experiments treating $\mathrm{FWW}$ with $\mathrm{TiO}_{2} \mathrm{NPs}$, the production of $\mathrm{NO}_{2}-\mathrm{N}$ and $\mathrm{NO}_{3}-\mathrm{N}$ by activated sludge was affected for the NPs. This means that $\mathrm{TiO}_{2} \mathrm{NPs}$ in wastewater without TSS may damage the aerobic oxidizing bacteria $(\mathrm{AOB})$ of the activated sludge, which has been recently demonstrated by sequencing the activated sludge exposed to TiO2 NPs (Li et al. 2020). Li et al. (2020) performed a quantitative polymerase chain reaction (qPCR) tests followed by Illumina high-throughput sequencing of the activated sludge exposed to a high cumulative concentration of $\mathrm{TiO}_{2} \mathrm{NPs}$ (450-900 $\mathrm{mg} / \mathrm{L}$ ) and found that $\mathrm{AOB}$ are mainly affected by acute exposition to these NPs.

In general, ammoniacal nitrogen removal was affected in the presence of $\mathrm{TiO}_{2} \mathrm{NPs}$ regardless of the type of wastewater. However, first and second steps of nitrification in presence of $\mathrm{TiO}_{2} \mathrm{NPs}$ were better performed using RWW than FWW. Considering that the only difference between FWW and RWW is the TSS content, the presence of suspended solids may contribute to the formation of heteroaggregates less toxic for nitrifying bacteria (Nitrobacter, Nitrosospira and Nitrosomonas). In contrast, for the experiments using the SWW and FWW, deficiencies in the production of nitrite and nitrate were found under the presence of $\mathrm{TiO}_{2} \mathrm{NPs}$, which could be attributed to damage in the nitrifying bacteria. The limited production of nitrite and nitrate in experiments treating SWW and FWW suggests that the overall removal of ammoniacal nitrogen in the presence of NPs could occur due to the adsorption of nitrogen onto $\mathrm{TiO}_{2}$ NPs. Adsorption of nitrogen compounds in SWW has been reported for $\mathrm{CeO}_{2} \mathrm{NPs}$ (Gómez-Rivera et al. 2012), which are non-soluble NPs such as $\mathrm{TiO}_{2}$ NPs at the experimental $\mathrm{pH}(7-8)$. In general, the nitrogen removal processes performed by activated sludge exposed to $\mathrm{TiO}_{2} \mathrm{NPs}$ have been affected regardless of the type of wastewater. Although NPs can damage the nitrification processes, especially for synthetic media and real wastewater without suspended solids, the nitrogen removal could be carried out by physicochemical mechanisms, such as adsorption of nitrogen compounds on $\mathrm{TiO}_{2} \mathrm{NPs}$.

\subsection{Orthophosphate removal in presence of $\mathrm{TiO}_{2} \mathrm{NPs}$}

The orthophosphate removal in the activated sludge process containing $\mathrm{TiO}_{2} \mathrm{NPs}$ was enhanced for all three types of wastewater (Fig. 4). In experiments with SWW, the highest $\mathrm{PO}_{4}{ }^{-3}$ removal was observed in the presence of $1000 \mathrm{mg} / \mathrm{L}$ of $\mathrm{TiO}_{2} \mathrm{NPs}$, with $34 \%$ higher removal than the control group. However, the most noticeable improvement was observed for experiments with real wastewater, which increased the removal of $\mathrm{PO}_{4}{ }^{-3}$ as the concentration of $\mathrm{TiO}_{2} \mathrm{NPs}$ increased. The percentages of enhancement when compared to their respective control groups were $16 \%$ and $55 \%$ for RWW and FWW, respectively. This suggests a direct action of NPs over $\mathrm{PO}_{4}{ }^{-3}$, such as adsorption or precipitation. 
Phosphorus removal during activated sludge process is developed by polyphosphate accumulating organisms (PAO), which capture the chains of polyphosphates under aerobic conditions. Since $\mathrm{TiO}_{2} \mathrm{NPs}$ may affect the bacterial performance, the possible explanation of phosphate removal could be the adsorption and co-precipitation of $\mathrm{PO}_{4}{ }^{-3}$ adsorbed by TiO2 NPs (Qian et al. 2017; Zhang et al. 2019). The ability of $\mathrm{TiO}_{2} \mathrm{NPs}$ for adsorbing compounds has been already reported (Cervantes-Avilés et al. 2017), including those measured as SCOD such as the polyphosphate chains present in activated sludge reactors. The adsorption of phosphate in NPs surface is related to the $\mathrm{pH}$ of the aqueous medium and $\mathrm{pH}$ between 7 and 8, the typical of activated sludge, is the most favored (Rathnayake et al. 2014). Moreover, the type of substrates in wastewater containing phosphate could also be an influencing factor (Neale et al. 2015), hence further evaluation of NPs for phosphorus removal or recovery should be addressed. Since the $\mathrm{pH}$ of the experiments in the present study was between 7-7.8, and the sources of $\mathrm{PO}_{4}{ }^{3-}$ in real wastewater are commonly detergents, the $\mathrm{TiO}_{2} \mathrm{NPs}$ could be an adsorbent agent during wastewater treatment.

The removal of orthophosphate via $\mathrm{TiO}_{2} \mathrm{NPs}$ could be considered as a positive effect that is due to potential adsorption. However, the affinity between $\mathrm{TiO}_{2} \mathrm{NPs}$ and orthophosphate should be proven through measuring orthophosphate adsorption capacity by $\mathrm{TiO}_{2} \mathrm{NPs}$, and other parameters that complement the characterization of NPs, such as zeta potential, specific surface area, among others. Considering that $\mathrm{TiO}_{2} \mathrm{NPs}$ are widely investigated for water treatment due their photocatalytic activity, and their potential contribution to the extracellular electron transfer (Wang et al. 2016), the ability of $\mathrm{TiO}_{2}$ NPs to remove orthophosphate from wastewater could promote their use during biological wastewater treatment.

\subsection{Effect of $\mathrm{TiO}_{2}$ NPs in the floc size and SVI of activated sludge}

The distribution of floc size of activated sludge in the three wastewater types is observed in Fig. 5. For all different types of wastewater, the flocs size of activated sludge was not affected by the presence of $\mathrm{TiO}_{2}$ NPs in the reactors. However, the average values of SVI in presence of $\mathrm{TiO}_{2} \mathrm{NPs}$ were $50 \%$ lower than control SVI values for all types of wastewater (Fig. 6), improving the compaction of activated sludge.

The activated sludge compaction during settling was dependent on the NPs content. This was observed in the SVI values, which were inversely proportional to the concentration of $\mathrm{TiO}_{2} \mathrm{NPs}$ regardless of the type of wastewater used (Fig. 6). These findings suggest that the flocs exposed to $\mathrm{TiO}_{2} \mathrm{NPs}$ kept the same size but had a higher density, settling faster and gaining greater compaction of biomass in reactors with the highest concentration of NPs. Despite of the compaction of flocs by the potential adsorption of $\mathrm{NPs}$, the microorganisms present in the activated sludge and exposed to $\mathrm{TiO}_{2} \mathrm{NPs}$ performed metabolic activities that allowed the treatment of wastewater regardless of the type of substrate, as indicated by the results about the removal of macronutrients. In previous experiments, $\mathrm{TiO}_{2} \mathrm{NPs}$ at cumulative concentrations of (nearly $120 \mathrm{mg} / \mathrm{L}$ ) have decreased the SVI of activated sludge in a sequential batch 
reactor (Qiu et al. 2016). However, some other nanomaterials have induced changes in size and stability of flocs such as $\mathrm{CuO}$ (Hou et al. 2015), $\mathrm{CeO}_{2}$ (You et al. 2016) and graphene-oxide (Ahmed and Rodrigues 2013), which led to an increased in both SVI and turbidity values. The improvement in the biomass compaction can be considered as positive effect when $\mathrm{TiO}_{2}$ NPs arrive to WWTP, especially to the primary and secondary clarifiers.

\subsection{Morphological interactions between $\mathrm{TiO}_{2} \mathrm{NPs}$ and activated sludge}

The way $\mathrm{TiO}_{2} \mathrm{NPs}$ interact with microorganisms was elucidated by electron microscopy. TEM imaging was performed for embedded samples of activates sludge exposed to $\mathrm{TiO}_{2} \mathrm{NPs}$, treating all three types of wastewater. During TEM observation, electrodense and particulate material (black color) was observed attached to the membrane of microorganisms (Fig. 7), presumably $\mathrm{TiO}_{2} \mathrm{NPs}$. This electrodense material presented aggregates smaller than $500 \mathrm{~nm}$, and in some of the samples were surrounded by organic material (grey color). These aggregates are consistent with the description of heteroaggregates proposed by Sani-Kast et al. (2015) and Dale et al. (2015). The integrity of the cell membrane of microorganisms in the control and SWW imaging is similar (Fig. 7A and B), without internalized electro-dense material. A similar pattern was observed for the sample of the experiment treating FWW (Fig. 7D). However, in the case of the experiment treating RWW (Fig. 7C), electrodense material as crystals and abundant cellular detritus were observed. This indicates that, in addition to the $\mathrm{TiO}_{2} \mathrm{NPs}$ supplied in the experiments, the RWW already contains water-insoluble metallic material. Although internalization of some NPs such as ZnO (Sirelkhatim et al. 2015; Cervantes-Avilés et al. 2016) and CuO (Perreault et al. 2012) has previously been considered as a pattern that leads to apoptosis of cells, the internalization of electrodense material in cells was not observed for the samples analyzed. Electrodense material was frequently observed attached to the cell membrane. In order to confirm that electrodense particulate material correspond to $\mathrm{TiO}_{2} \mathrm{NPs}$, elemental mapping was performed in the sample of activated sludge treating RWW.

In the elemental mapping of activated sludge exposed to $\mathrm{TiO}_{2} \mathrm{NPs}$ treating $\mathrm{RWW}$, the electrodense material was confirmed to correspond to $\mathrm{Ti}$ (Fig. 8). By overlapping the layers of $\mathrm{Ti}-\mathrm{K}, \mathrm{Ti}-\mathrm{L}$, and $\mathrm{O}-\mathrm{K}$, it can be concluded that $\mathrm{Ti}$ corresponds to $\mathrm{TiO}_{2}$ at the nanoscale. The distribution of $\mathrm{Ti}$ in the micrograph captured in HAADF-STEM confirmed that this material is attached to the cell membrane (Fig. 8). Therefore, one of the mechanisms by which $\mathrm{TiO}_{2} \mathrm{NPs}$ could harm microorganisms is through damage to the cell membrane, such as disruption. Some studies about the toxicity of $\mathrm{TiO}_{2} \mathrm{NPs}$ in isolated microorganisms reported the chemical activity of these particles on the phospholipid membrane of cells (Ma and Lin 2013; Neale et al. 2015). Moreover, $\mathrm{TiO}_{2}$ NPs have biocide effect when exposed to UV radiation as demonstrated by previous studies (Cai et al. 2014; Qian et al. 2017). Since our experiments were performed without exposition to UV light, the main mechanism of damage from $\mathrm{TiO}_{2} \mathrm{NPs}_{\text {to }}$ microorganisms of activated sludge possibly occurs through physical interactions conducting to the cell membrane rupture (Ma and Lin 2013). This would lead to lysis of microorganisms present in activated sludge, affecting the processes involved in the biological macronutrient removal from wastewater. 


\section{Conclusions}

In this work, the effects of the type of wastewater such as synthetic, raw, and filtered, in the removal of macronutrients by the activated sludge process exposed to $\mathrm{TiO}_{2} \mathrm{NPs}$ were evaluated. From the results obtained it is concluded that:

- The removal of organic matter in raw and filtered wastewater by activated sludge decreased up to $14 \%$ in the presence of $2000 \mathrm{mg} / \mathrm{L}$ of $\mathrm{TiO}_{2} \mathrm{NPs}$.

- Ammoniacal nitrogen removal during the treatment of synthetic, raw, and filtered wastewater was inhibited in the presence of concentrations greater than $500 \mathrm{mg} / \mathrm{L}$ of $\mathrm{TiO}_{2} \mathrm{NPs}$. The most representative impact was the inhibition of $22 \%$ of ammoniacal nitrogen removal for the highest load of $\mathrm{TiO}_{2} \mathrm{NPs}$. Although deficiencies in the production of nitrite and nitrate were observed for synthetic and filtered wastewater, the removal of ammoniacal nitrogen for these types of wastewater in presence of NPs could occur via adsorption on $\mathrm{TiO}_{2} \mathrm{NPs}$.

- Orthophosphate removal in activated sludge bioreactors improved linearly to the concentration of $\mathrm{TiO}_{2} \mathrm{NPs}$, regardless the type of wastewater fed to the reactors. This can be considered as a positive effect of $\mathrm{TiO}_{2} \mathrm{NPs}$ in the activated sludge process.

- The main interaction between $\mathrm{TiO}_{2}$ NPs and activated sludge flocs was the adsorption of NPs over the cell membrane of microorganisms, without internalization of the NPs. This adsorption did not affect the floc size of activated sludge flocs; however, it increased the density of flocs improving the compaction of activated sludge during the treatment of all types of wastewater used in the experiments.

The use of real wastewater in ecotoxicological experiments of NPs is highly encouraged due to effects of NPs were limited for synthetic substrate. Moreover, the most adverse effects were detected for real matrices of wastewater. Furthermore, although activated sludge still removes macronutrients in the presence of high load of $\mathrm{TiO}_{2} \mathrm{NPs}$, the removal mechanisms could be physicochemical rather than biological.

\section{Declarations}

\section{Ethical Approval}

Not applicable.

\section{Consent to participate}

Not applicable.

\section{Consent to publish}

Not applicable. 
Authors contributions

Cervantes-Avilés: conceptualization, methodology, investigation, writing of original draft; writing review \& edition, funding acquisition; A.N. Saber: data curation, formal analysis, writing of original draft, writing review \& edition; A. Mora Polanco: formal analysis, writing review \& edition; conceptualization; J. Mahlknecht: formal analysis, writing review \& edition; G. Cuevas-Rodríguez: data curation, resources, supervision, funding acquisition, project administration, writing review \& edition.

\section{Funding}

This work was supported by the Research Direction and Support to Postgraduate of the University of Guanajuato. Pabel Cervantes-Avilés received funding from National Council of Science and Technology of Mexico and from Sciences Department of Tecnologico de Monterrey Campus Puebla.

\section{Competing interests}

The authors declare that they have no competing interests.

\section{Data availability}

The datasets used and analyzed during the current study are available from the corresponding author on reasonable request.

\section{References}

1. Adam V, Caballero-Guzman A, Nowack B (2018) Considering the forms of released engineered nanomaterials in probabilistic material flow analysis. Environ Pollut 243:17-27. https://doi.org/10.1016/j.envpol.2018.07.108

2. Ahmed F, Rodrigues DF (2013) Investigation of acute effects of graphene oxide on wastewater microbial community: a case study. J Hazard Mater 256-257:33-39

3. APHA (2005) Standard Methods for the Examination of Water and Wastewater. Stand Methods 541. https://doi.org/ISBN 9780875532356

4. Brar SK, Verma M, Tyagi RD, Surampalli RY (2010) No Title. Waste Manag 30:504

5. Cai Y, Strømme M, Welch K (2014) Disinfection Kinetics and Contribution of Reactive Oxygen Species When Eliminating Bacteria with TiO2 Induced Photocatalysis. J Biomater Nanobiotechnol 05:200209. https://doi.org/10.4236/jbnb.2014.53024

6. Cervantes-Avilés P, Brito EMS, Duran R et al (2016) Effect of ZnO nanoparticles in the oxygen uptake during aerobic wastewater treatment. J Nanoparticle Res 18.. https://doi.org/10.1007/s11051-016$3481-3$

7. Cervantes-Avilés P, Camarillo Piñas N, Ida J, Cuevas-Rodríguez G (2017) Influence of wastewater type on the impact generated by $\mathrm{TiO} 2$ nanoparticles on the oxygen uptake rate in activated sludge 
process. J Environ Manage 190:35-44. https://doi.org/10.1016/j.jenvman.2016.12.054

8. Cervantes-Avilés P, Ida J, Toda T, Cuevas-rodríguez G (2018) Effects and fate of TiO 2 nanoparticles in the anaerobic treatment of wastewater and waste sludge. 222:227-233.

https://doi.org/10.1016/j.jenvman.2018.05.074

9. Cervantes-Avilés P, Keller AA (2021) Incidence of metal-based nanoparticles in the conventional wastewater treatment process. Water Res 189:. https://doi.org/10.1016/j.watres.2020.116603

10. Dale AL, Lowry GV, Casman EA (2015) Stream Dynamics and Chemical Transformations Control the Environmental Fate of Silver and Zinc Oxide Nanoparticles in a Watershed-Scale Model. Environ Sci Technol 49:7285-7293. https://doi.org/10.1021/acs.est.5b01205

11. García A, Delgado L, Torà JA et al (2012) Effect of cerium dioxide, titanium dioxide, silver, and gold nanoparticles on the activity of microbial communities intended in wastewater treatment. J Hazard Mater 199-200:64-72. https://doi.org/10.1016/j.jhazmat.2011.10.057

12. Gartiser S, Flach F, Nickel C et al (2014) Behavior of nanoscale titanium dioxide in laboratory wastewater treatment plants according to OECD 303 A. Chemosphere 104:197-204. https://doi.org/10.1016/j.chemosphere.2013.11.015

13. Gómez-Rivera F, Field JA, Brown D, Sierra-Alvarez R (2012) Fate of cerium dioxide (CeO 2) nanoparticles in municipal wastewater during activated sludge treatment. Bioresour Technol 108:300-304. https://doi.org/10.1016/j.biortech.2011.12.113

14. Hotze EM, Phenrat T, Lowry GV (2010) Nanoparticle Aggregation: Challenges to Understanding Transport and Reactivity in the Environment. J Environ Qual 39:1909. https://doi.org/10.2134/jeq2009.0462

15. Hou J, Miao L, Wang C et al (2015) Effect of CuO nanoparticles on the production and composition of extracellular polymeric substances and physicochemical stability of activated sludge flocs. Bioresour Technol 176:65-70. https://doi.org/10.1016/j.biortech.2014.11.020

16. Huang Y, Keller AA, Cervantes-Avilés P, Nelson J (2020) Fast Multielement Quantification of Nanoparticles in Wastewater and Sludge Using Single-Particle ICP-MS. ACS ES\&T Water. https://doi.org/10.1021/acsestwater.0c00083

17. Keller AA, Cherr G, Cardinale BJ et al (2010) Stability and Aggregation of Metal Oxide Nanoparticles in Natural Aqueous Matrices. 44:1962-1967. https://doi.org/10.1021/es902987d

18. Keller AA, Lazareva A (2013) Predicted Releases of Engineered Nanomaterials: From Global to Regional to Local. Environ Sci Technol Lett 1:65-70. https://doi.org/10.1021/ez400106t

19. Kiser MA, Westerhoff $P$, Benn T et al (2009) Titanium Nanomaterial Removal and Release from Wastewater Treatment Plants. Environ Sci Technol 43:6757-6763. https://doi.org/10.1021/es901102n

20. Kunhikrishnan A, Shon HK, Bolan NS et al (2015) Sources, distribution, environmental fate, and ecological effects of nanomaterials in wastewater streams. Crit Rev Environ Sci Technol 45: https://doi.org/10.1080/10643389.2013.852407 
21. Li K, Qian J, Wang P et al (2020) Differential responses of encoding-amoA nitrifiers and nir denitrifiers in activated sludge to anatase and rutile TiO2 nanoparticles: What is active functional guild in rate limiting step of nitrogen cycle? J Hazard Mater 384:. https://doi.org/10.1016/j.jhazmat.2019.121388

22. Li Z, Wang X, Ma B et al (2017) Long-term impacts of titanium dioxide nanoparticles (TiO2 NPs) on performance and microbial community of activated sludge. Bioresour Technol 238:361-368. https://doi.org/10.1016/j.biortech.2017.04.069

23. Ma S, Lin D (2013) The biophysicochemical interactions at the interfaces between nanoparticles and aquatic organisms: Adsorption and internalization. Environ Sci Process Impacts 15:145-160. https://doi.org/10.1039/c2em30637a

24. Ma Y, Metch JW, Vejerano EP et al (2015) Microbial community response of nitrifying sequencing batch reactors to silver, zero-valent iron, titanium dioxide and cerium dioxide nanomaterials. Water Res 68:87-97. https://doi.org/10.1016/j.watres.2014.09.008

25. Neale PA, Jämting AK, O'Malley E et al (2015) Behaviour of titanium dioxide and zinc oxide nanoparticles in the presence of wastewater-derived organic matter and implications for algal toxicity. Environ Sci Nano 2:86-93. https://doi.org/10.1039/c4en00161c

26. Perreault F, Oukarroum A, Melegari SP et al (2012) Polymer coating of copper oxide nanoparticles increases nanoparticles uptake and toxicity in the green alga Chlamydomonas reinhardtii. Chemosphere 87:1388-1394. https://doi.org/10.1016/j.chemosphere.2012.02.046

27. Polesel F, Farkas J, Kjos M et al (2018) Occurrence, characterisation and fate of (nano)particulate Ti and $\mathrm{Ag}$ in two Norwegian wastewater treatment plants. Water Res 141:19-31. https://doi.org/10.1016/j.watres.2018.04.065

28. Qian J, Li K, Wang P et al (2017) Toxic effects of three crystalline phases of TiO2 nanoparticles on extracellular polymeric substances in freshwater biofilms. Bioresour Technol 241:276-283. https://doi.org/10.1016/j.biortech.2017.05.121

29. Qiu G, Au MJ, Ting YP (2016) Impacts of Nano-TiO2 on System Performance and Bacterial Community and Their Removal During Biological Treatment of Wastewater. Water Air Soil Pollut 227:. https://doi.org/10.1007/s11270-016-3081-y

30. Rathnayake S, Unrine JM, Judy J et al (2014) Multitechnique investigation of the ph dependence of phosphate induced transformations of ZnO nanoparticles. Environ Sci Technol 48:4757-4764. https://doi.org/10.1021/es404544w

31. Sani-Kast N, Scheringer M, Slomberg D et al (2015) Addressing the complexity of water chemistry in environmental fate modeling for engineered nanoparticles. Sci Total Environ 535:150-159. https://doi.org/10.1016/j.scitotenv.2014.12.025

32. Sirelkhatim A, Mahmud S, Seeni A et al (2015) Review on zinc oxide nanoparticles: Antibacterial activity and toxicity mechanism. Nano-Micro Lett 7:219-242. https://doi.org/10.1007/s40820-0150040-x 
33. Supha C, Boonto $Y$, Jindakaraked M, et al (2015) Long-term exposure of bacterial and protozoan communities to $\mathrm{TiO}<\mathrm{inf}>2</$ inf $>$ nanoparticles in an aerobic-sequencing batch reactor. Sci Technol Adv Mater 16:. https://doi.org/10.1088/1468-6996/16/3/034609

34. Taurozzi JS, Hackley VA, Wiesner MR (2012) Preparation of Nanoparticle Dispersions from Powdered Material Using Ultrasonic Disruption. Spec Publ (NIST SP). https://doi.org/10.6028/NIST.SP.1200-2

35. Tuoriniemi J, Cornelis G, Hassellöv M (2012) Size discrimination and detection capabilities of singleparticle ICPMS for environmental analysis of silver nanoparticles. Anal Chem 84:3965-3972. https://doi.org/10.1021/ac203005r

36. van Loosdrecht MC, Nielsen PH, Lopez-Vazquez CM, Brdjanovic D (2016) Experimental Methods in Wastewater Treatment

37. Wang G, Feng H, Gao A et al (2016) Extracellular Electron Transfer from Aerobic Bacteria to AuLoaded TiO2 Semiconductor without Light: A New Bacteria-Killing Mechanism Other than Localized Surface Plasmon Resonance or Microbial Fuel Cells. ACS Appl Mater Interfaces 8:24509-24516. https://doi.org/10.1021/acsami.6b10052

38. Weir A, Westerhoff P, Fabricius $L$ et al (2012) Titanium dioxide nanoparticles in food and personal care products. Environ Sci Technol 46:2242-2250. https://doi.org/10.1021/es204168d

39. You G, Hou J, Wang P et al (2016) Effects of Ce02nanoparticles on sludge aggregation and the role of extracellular polymeric substances - Explanation based on extended DLVO. Environ Res 151:698705. https://doi.org/10.1016/j.envres.2016.08.023

40. Zhang F, Lee MH, Huang $Y$ et al (2019) Effective water disinfection using magnetic barium phosphate nanoflakes loaded with Ag nanoparticles. J Clean Prod 218:173-182. https://doi.org/10.1016/j.jclepro.2019.01.232

41. Zheng X, Chen Y, Wu R (2011) Long-Term Effects of Titanium Dioxide Nanoparticles on Nitrogen and Phosphorus Removal from Wastewater and Bacterial Community Shift in Activated Sludge. Environ Sci Technol 45:7284-7290. https://doi.org/10.1021/es2008598

42. Zhou $X$, Huang B, Zhou T et al (2015) Aggregation behavior of engineered nanoparticles and their impact on activated sludge in wastewater treatment. Chemosphere 119:568-576. https://doi.org/http://dx.doi.org/10.1016/j.chemosphere.2014.07.037

\section{Figures}



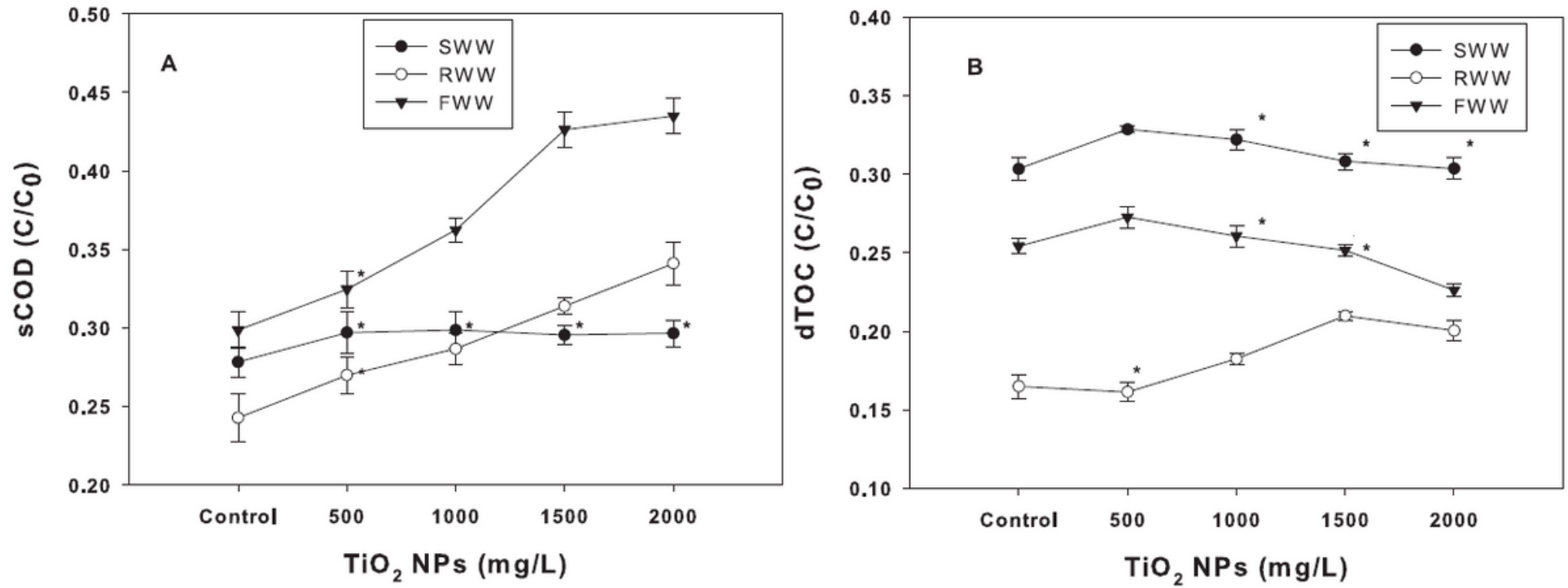

Figure 1

Effect of TiO2 NPs in the organic matter removal from synthetic wastewater (SWW), raw wastewater (RWW), and filtered wastewater (FWW), measured as: A) Soluble chemical oxygen demand (SCOD) and B) Dissolved total organic carbon (dTOC). Note: " $\star$ " means that there was no significant difference to the control.

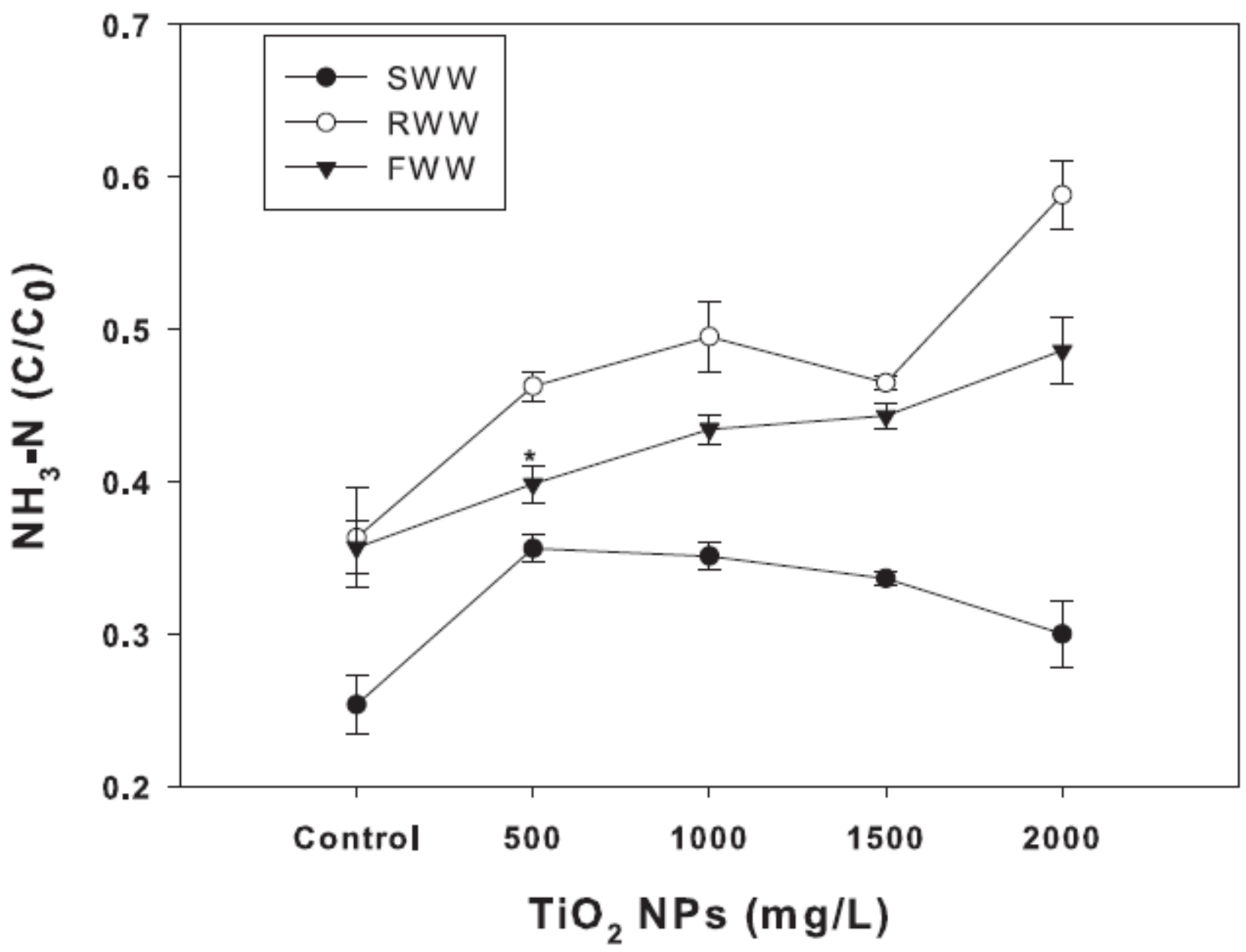

Page $17 / 23$ 
Figure 2

Ammoniacal nitrogen removal in the activated sludge process exposed to different concentrations of TiO2 NPs expressed as the ratio between final (C) and initial concentration (C0) of ammoniacal nitrogen after $8 \mathrm{~h}$ of treatment of synthetic wastewater (SWW), raw wastewater (RWW) and filtered wastewater (FWW). Note: " $\star$ " means that there was no significant difference to the control.
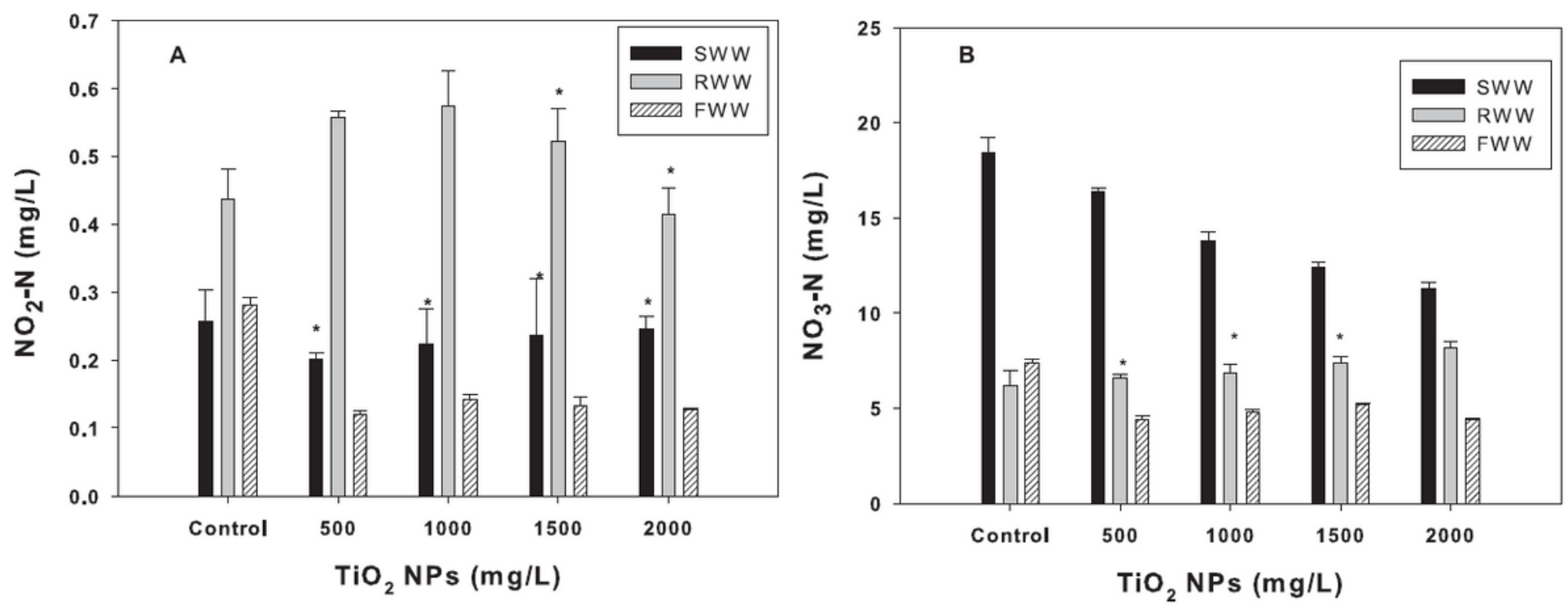

Figure 3

Effect of TiO2 NPs in the formation of: A) Nitrite (NO2-N) and B) Nitrate (NO3-N), which were measured at the end of the treatment of synthetic wastewater (SWW), raw (RWW) and filtered (FWW). Note: " $\star$ " means that there was no significant difference to the control. 


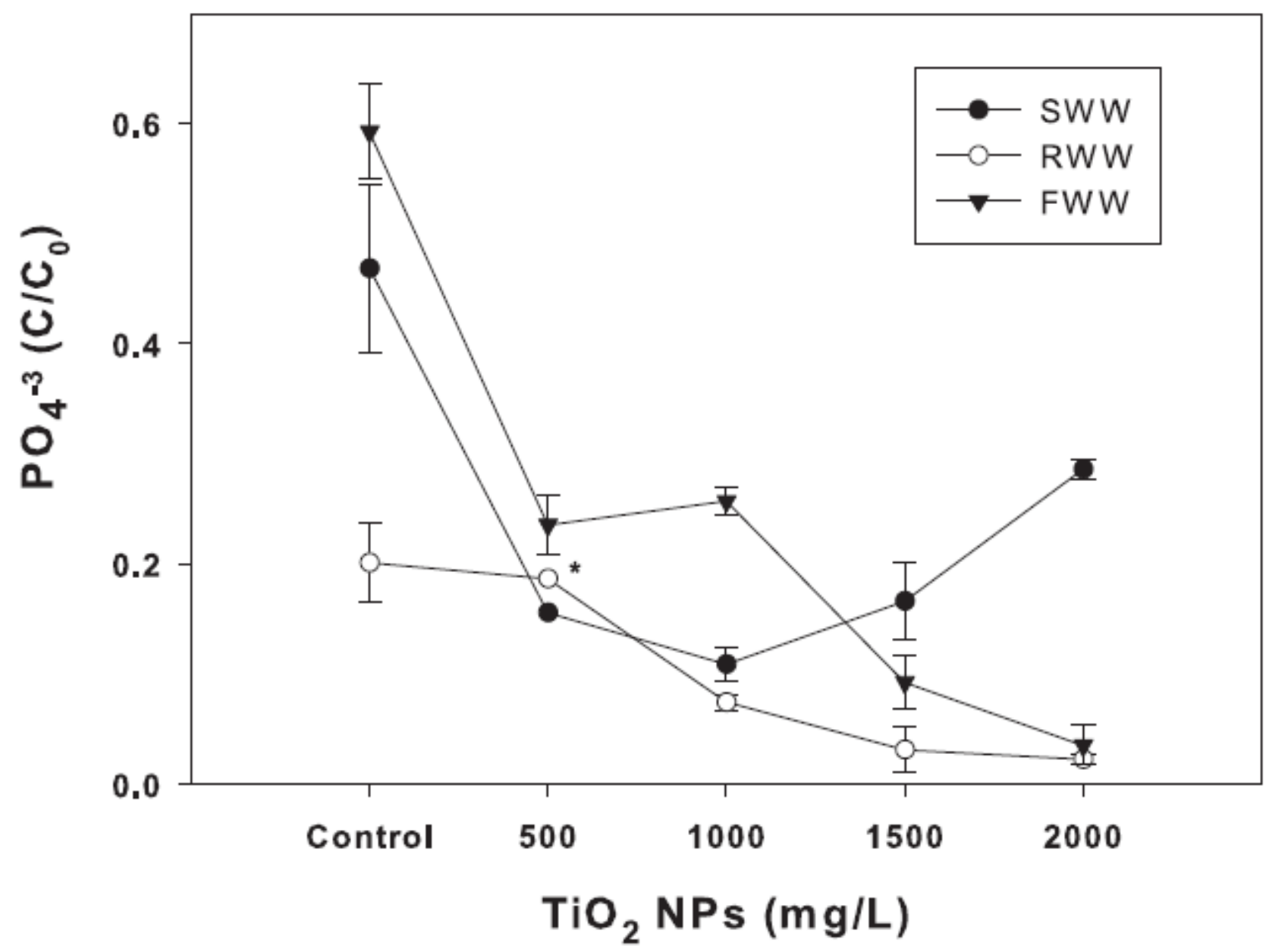

Figure 4

Orthophosphate (PO4-3) removal as the ratio of final (C) and initial (C0) concentration of P04-3 after $8 \mathrm{~h}$ of treatment by activated sludge of synthetic wastewater (SWW), raw wastewater (RWW) and filtered wastewater (FWW) exposed to TiO2 NPs. Note: "*” means that there was no significant difference to the control. 


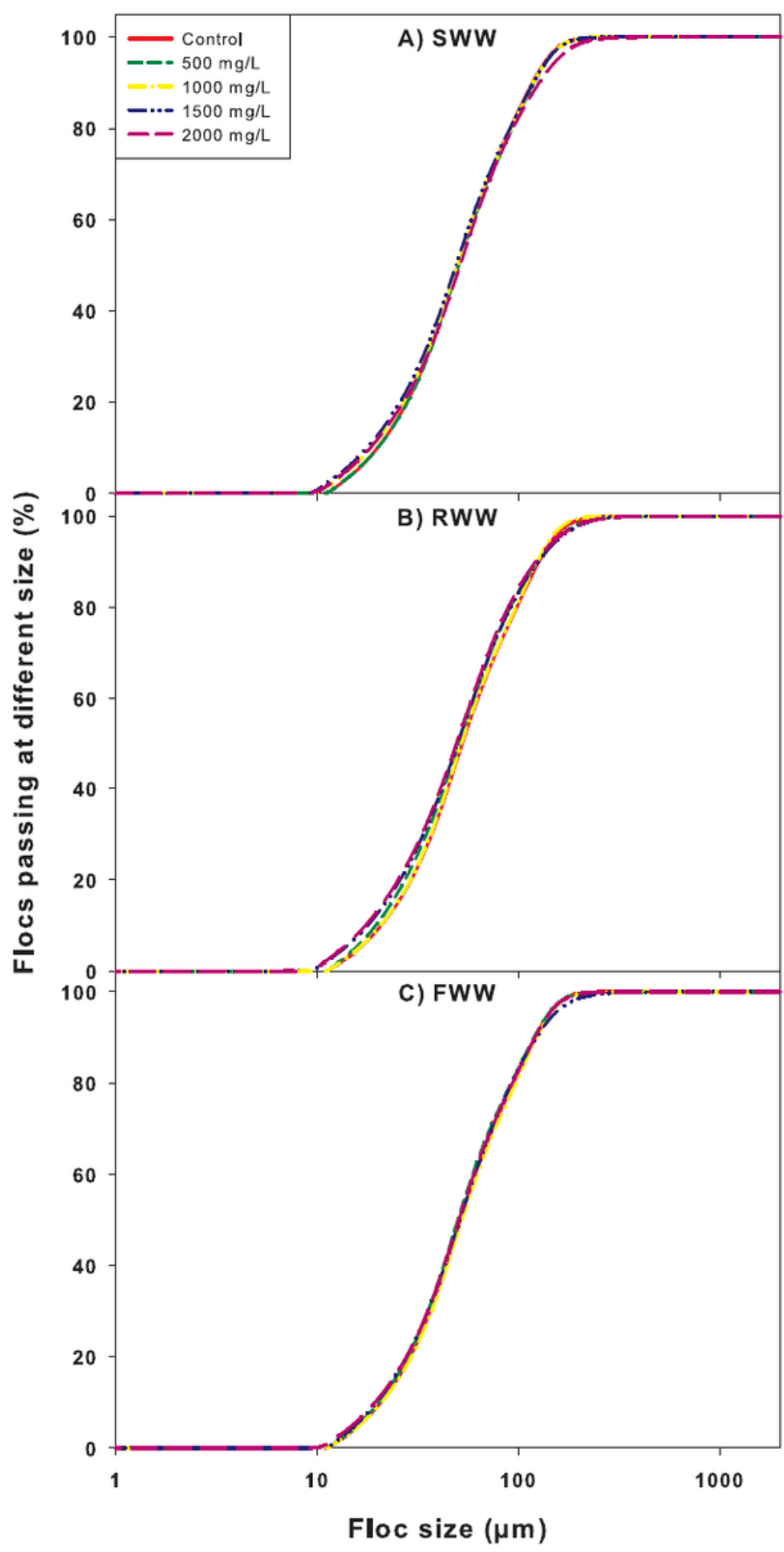

Figure 5

Size distribution of activated sludge flocs exposed to TiO2 NPs during treatment of: A) synthetic wastewater (SWW), B) raw wastewater (RWW) and C) Filtered wastewater (FWW). 


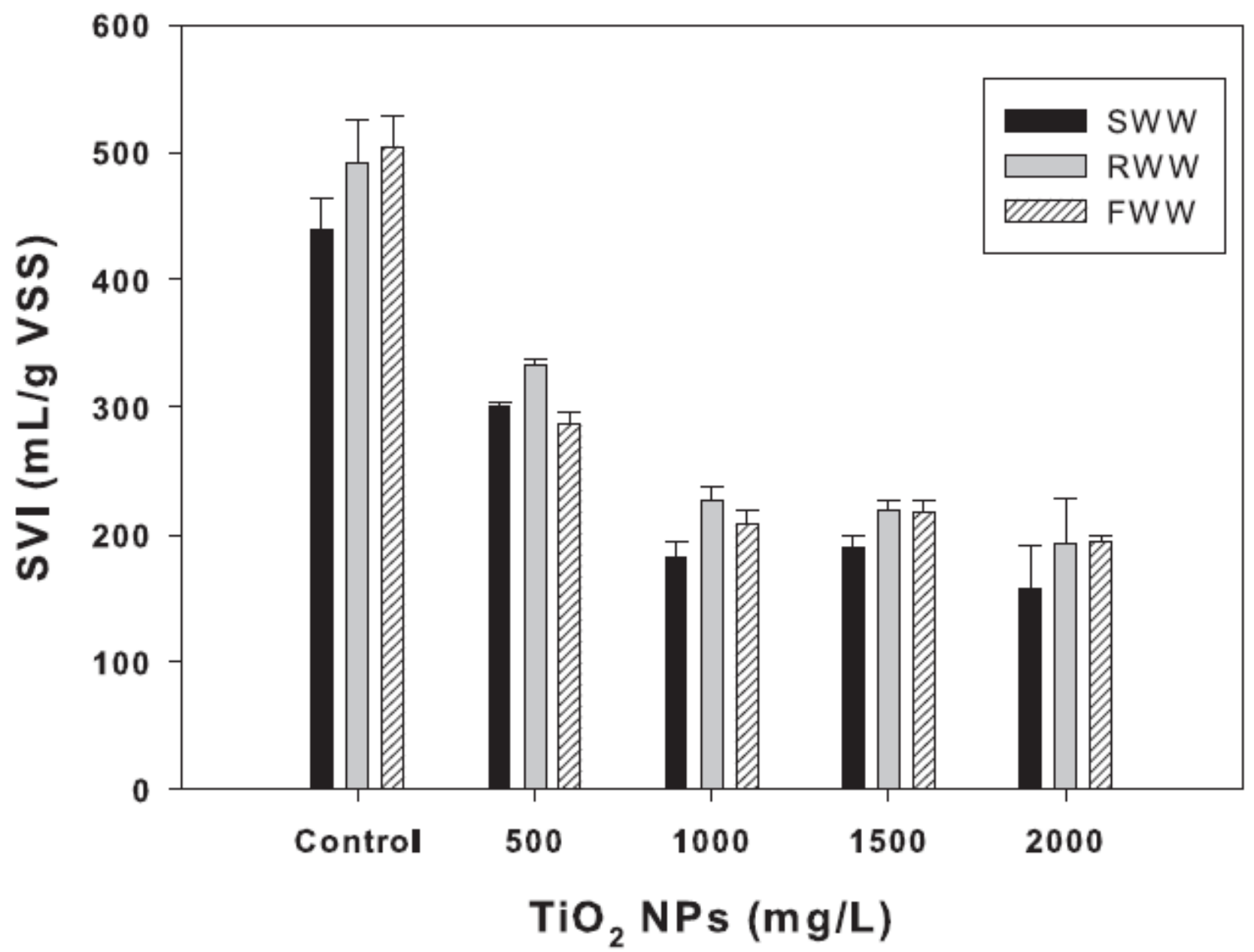

Figure 6

Sludge volume index (SVI) of activated sludge exposed to TiO2 NPs during the treatment of synthetic (SWW), raw wastewater (RWW) and filtered wastewater (FWW). 

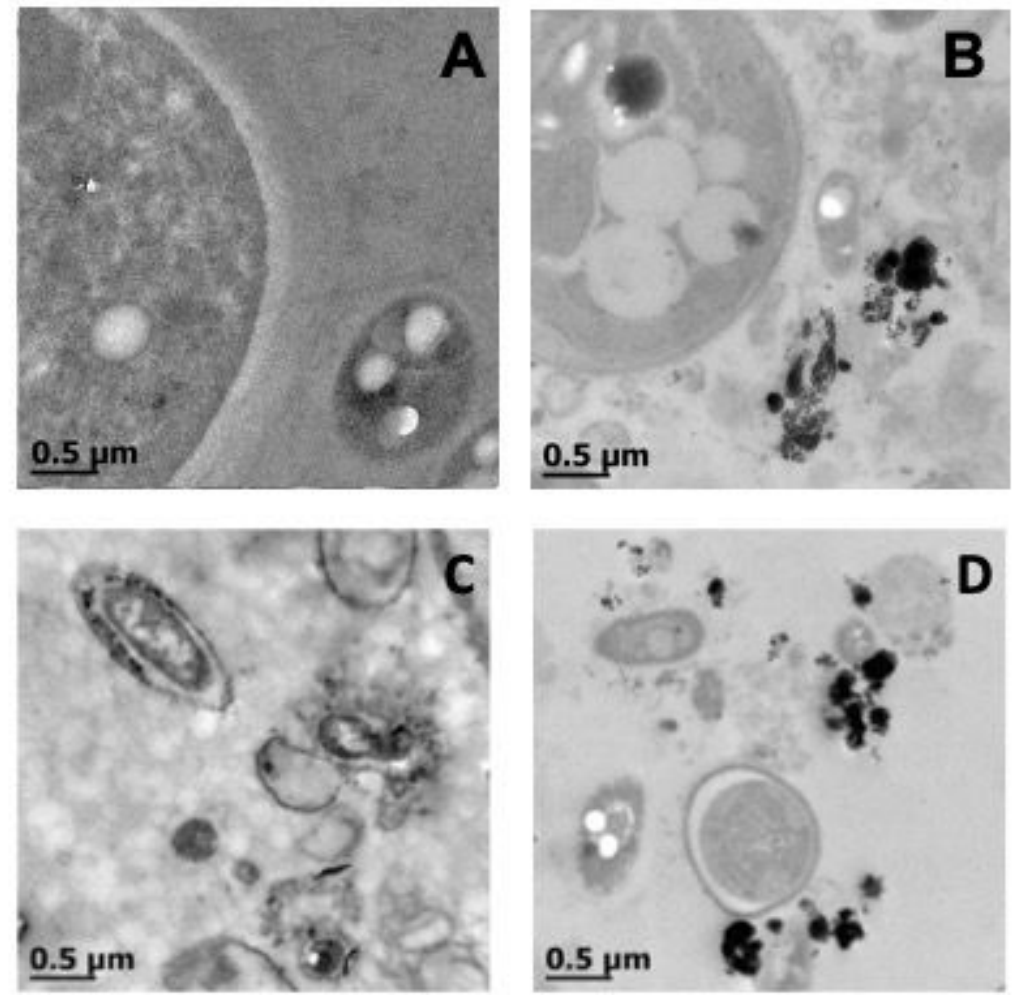

\section{Figure 7}

Transmission electron microscopy (TEM) imaging of microorganisms present in aerobic wastewater treatment exposed to TiO2 NPs. A) Control treating RWW; B) SWW $+1000 \mathrm{mg} / \mathrm{L}$ of TiO2 NPs; C) RWW + $1000 \mathrm{mg} / \mathrm{L}$ of TiO2 NPs; D) FWW $+2000 \mathrm{mg} / \mathrm{L}$ of TiO2 NPs. 

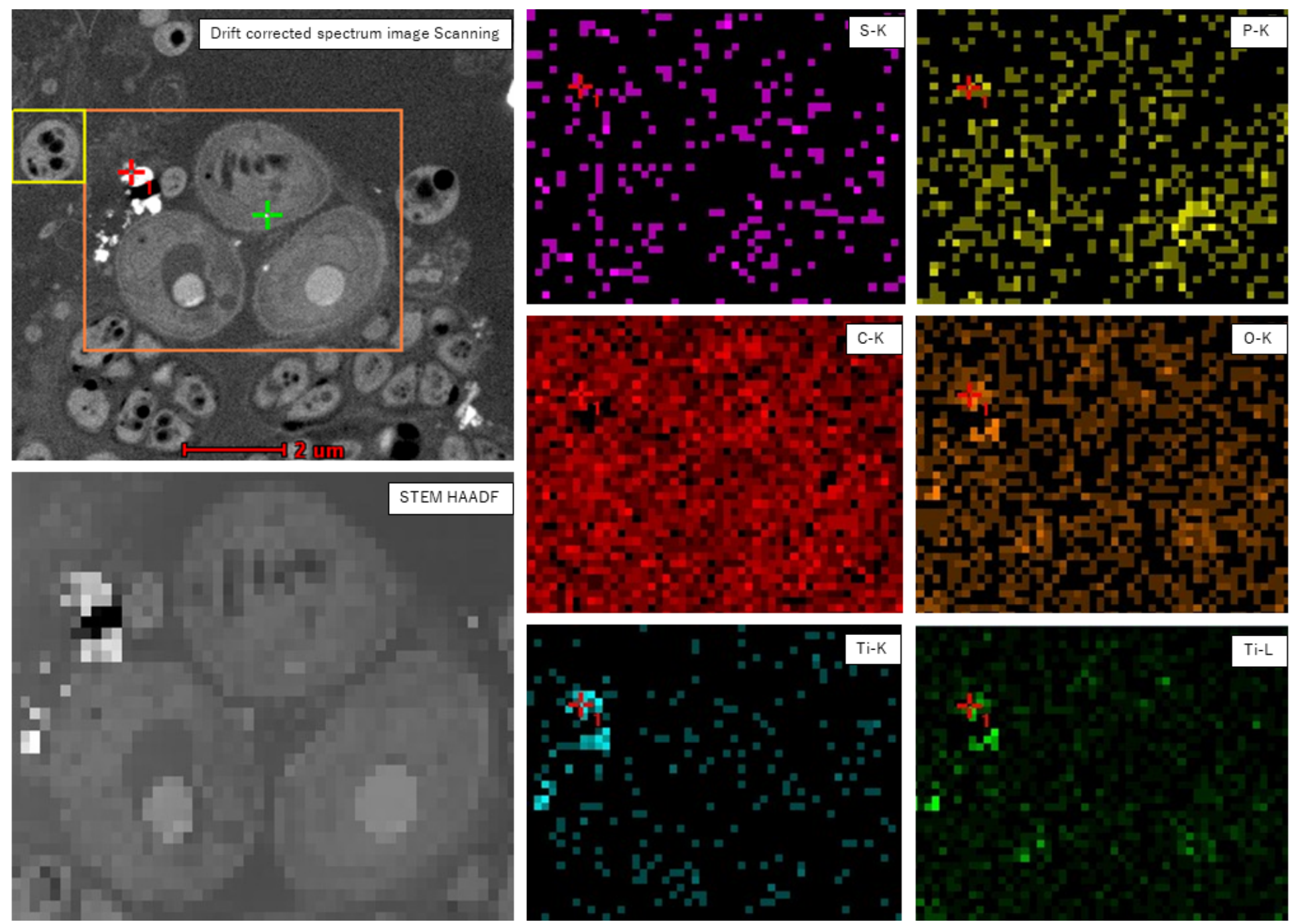

Figure 8

Elemental mapping of S-K, P-K, C-K, O-K, Ti-K and Ti-L in activated sludge exposed to raw wastewater (RWW) containing $1000 \mathrm{mg} / \mathrm{L}$ of TiO2 NPs. 